\title{
1. Introduction: How to study trade union action towards immigration and migrant workers?
}

\section{Stefania Marino, Rinus Penninx and Judith Roosblad}

\section{A NEW STUDY OF TRADE UNIONS AND MIGRANT WORKERS}

Migration issues are central to the current political discourse in Europe and are likely to remain a prominent theme in European politics for a long time to come. The discussion about the desirability of migrants has created political tensions in several countries. On the one hand, the role of migrant workers in the European labour market is seen as a necessity to strengthen national economies. On the other, migrants are perceived as outsiders who take jobs, sponge off welfare benefits and threaten social cohesion. These fears have been intensified in many European countries by economic recession, high unemployment and increases in precarious jobs. Populist political discourse has further contributed to anti-immigrant feelings, spreading the idea of an 'invasion' of migrants and refugees and of their links with the terrorist threat. Racism, xenophobia and hostility towards migrants are on the rise in Europe. Consequently, immigrant integration has become a major issue for governments at all levels (Penninx et al. 2006).

Trade unions have to take positions on these matters, based both on their own convictions and interests, and as actors in national labour market regulatory frameworks as well as in the international arena. An analysis of union stances towards immigration and migrant workers constituted the core theme of a book published in 2000 by two of the editors of the current volume, Rinus Penninx and Judith Roosblad. Trade Unions, Immigration, and Migrants in Europe, 1960-1993: A Comparative Study of the Attitudes and Actions of Trade Unions in Seven West European Countries offered a comparative analysis of how trade unions in seven north-west European countries looked at labour immigration, migrant 
workers and their families during these three decades and what action was undertaken by trade unions to include them in their rank and file.

Since then, trade unions in Europe have been confronted with migrant workers under changed conditions in the international economic order, in national and European labour market regulations, in industrial relations, in the process of Europeanization and European Union (EU) enlargement, and in international migrations. In addition, changing social and political trends such as the rise of xenophobia and the surge of the populist right, with substantial working-class support, are challenges trade unions now must face. These changes have an impact on the way trade unions currently deal with migration and migrant workers.

The issue of trade unions and migrant workers has become an important topic both in migration studies and among industrial relations researchers. Within the International Migration, Integration and Social Cohesion in Europe (IMISCOE) network, ${ }^{1}$ a special research cluster (Immigration, Immigrants and Trade Unions in Europe - IITUE) was established in 2011 with the aim of bringing together researchers from both disciplines to exchange knowledge and develop common research initiatives. It was within this research cluster that a new comparative study on trade unions and their relationship with immigration and migrants in Europe was proposed. The IITUE research cluster organized several panels at annual IMISCOE conferences and other workshops to recruit contributors and to develop the research project that is reported here.

The aim of the book is to provide an understanding of the relationship between trade unions and migrant workers in Europe from a comparative and cross-disciplinary perspective. It does this by taking the following steps: first, it reassesses the heuristic model used in the Penninx and Roosblad study and refines the basic questions to be asked in the empirical study of national cases; secondly, it analyses in detail important contextual changes that have occurred in the past 20 years and points towards the possible consequences for the relationship between trade unions and immigration and migrant workers; thirdly, it presents a structured empirical analysis of how trade unions in 11 European countries have reacted to immigration and migrant workers over the past two decades; and fourthly, it sets out a comparative discussion of the 11 national cases and attempts to account for the similarities and differences observed.

In this introductory chapter, we first briefly reiterate the approach and results of the 2000 book. This also sets a historical benchmark for how the issue played out in Europe before 1990-2015, the period we cover in this book. We then outline how we have developed the analytical framework and refined the questions for the empirical research by reassessing the approach of the 2000 study. We go on to discuss the methodology 
and the approach of our study. Finally, we outline the structure of the book.

\section{THE 2000 STUDY OF THE ATTITUDES AND ACTIONS OF TRADE UNIONS IN SEVEN WEST EUROPEAN COUNTRIES}

To guide the comparative description of the attitudes and actions of trade unions in seven north-west European countries, Penninx and Roosblad (2000: 1-12) developed an analytical framework that consisted of three basic dilemmas. The first dilemma was whether trade unions should resist employers' efforts or cooperate in recruiting workers from abroad. If unions do cooperate, it asks what terms they should try to establish for the employment of foreign workers. Cooperating could, after all, depress the wages of union members, and the availability of surplus labour might weaken trade union bargaining power. Yet resisting could slow down economic expansion.

The second dilemma arises when migrant workers actually arrive, regardless of whether they come 'spontaneously' or on demand: should migrant workers be regarded as an integral part of the trade union rank and file and therefore be actively recruited as members with the same rights as any other worker? The alternative is to partially or completely exclude foreign workers from union membership and workers' rights. Exclusion could drive a wedge into the labour movement, eventually weakening its negotiating position. Inclusion, however, might be seen as a threat to the interests of native workers.

If trade unions favour inclusion as a solution to the second dilemma, then the (real or alleged) differences between native and migrant workers lead to the third dilemma, that of equal versus special treatment. Should trade unions exclusively represent the common interests of native and migrant workers, treating all workers the same? Or should they develop targeted policies and strategies that cater to the special interests and needs of migrant members? While the former general strategies may imply injustices for migrant members, special policies risk alienating native members who might resent such 'preferential treatment' of migrants.

To explain the differences between trade union attitudes and actions in the seven case countries, Penninx and Roosblad (2000: 13-19) proposed looking at four sets of factors, and their inter-relationship within a national context, to explain the variation in outcomes (where explaining is not hinting at a causal relationship per se, but at a plausible prediction of specific reactions of trade unions under certain conditions). The first is the 
position and power that trade unions have in society and in national socioeconomic decision-making. The more powerful a trade union is, the more effective it will be in influencing the policies of government and employers' associations in union-advocated directions.

The second set of factors refers to the economy and labour market conditions. In times of plentiful national supply of labour, trade unions are likely to oppose the recruitment of migrant workers; while in times of labour shortages, unions will probably be more willing to cooperate. The state of the economy and labour market might also influence trade union responses to the second and third dilemmas. In times of widespread unemployment, competition (actual or presumed) between native and migrant workers might increase, making inclusive union policies difficult to maintain.

The third set of factors relates to social trends. Trade union policies towards immigration and migrants are influenced by contextual aspects such as the public discourse on immigration and migrants, institutional arrangements and legislation in this field, and the attitudes and actions of institutional actors such as national authorities, civil society organizations and political parties.

The final set of factors concerns the characteristics of migrants and public perceptions of immigration. Unions may be more sympathetic to migrants from former colonies, to those from countries where unions hold similar ideologies and to those perceived as culturally similar to the native population. For their part, migrants may also have characteristics that influence their ability or willingness to unionize. These include experiences of trade unions in their country of origin, educational level, legal status and duration of stay.

The findings of the comparative analysis can be summarized by saying that, notwithstanding similar worries and solidarity commitments among trade unions in the seven countries studied, the reactions to immigration and migrants in the period 1960-93 varied significantly (Penninx and Roosblad 2000: 183-211). Trade unions in Austria, West Germany, the Netherlands and Sweden, where unions were strongly involved in socio-economic policy-making with the state and employers, cooperated on immigration from a strong position. Their argument was as follows: if we cooperate in importing labour, it should be done in such a way as to not jeopardize labour relations and bargaining positions. To do so, they acquired direct control over recruitment procedures (including veto rights), demanded equal wages, work conditions and industrial rights for migrants, plus specific provisions for housing, travel and sometimes even language courses to be provided at the cost of the employer. In the cases of West Germany and the Netherlands, and less so in Sweden, unions 
also tried to ensure that employment was temporary and there was the possibility of reducing the imported labour force if necessary. In the case of Austria, the strong position of unions was explicitly used to 'protect the native workers' by keeping the annual quota as low as possible and by defining migrant labour as a special, temporary category that did not enjoy the same rights as native workers in a number of aspects. In Switzerland, France and the UK, trade unions were either not involved in national decision-making on migrant labour or had only a weak position. In these cases, unions could only criticize governmental labour migration policies from an opposing position.

The reactions as characterized above are trade unions' reactions before 1973, when the guest worker system ended. In the period that followed in the 1970s and 1980s, restructuring national economies in north-west Europe lost much of their autonomy in a globalizing world, within a new international division of labour in which labour-intensive industries were relocated elsewhere and capital-intensive production and the service sector became their core activities. Under such developments, national authorities tried to keep the number of migrants likely to be dependent on the welfare state as low as possible through restrictive and selective immigration policies. The alliance between governments and trade unions in favour of such restrictive immigration policies was a natural one: in none of the seven countries did trade unions oppose these policies. However, trade unions did stand up for what they regarded as the acquired rights of migrants, by opposing deportation and return programmes or restrictions on family reunification. In doing the latter, trade unions acted not so much as defenders of the interests of (migrant) workers per se, but as part of a larger social movement.

As to the second dilemma - inclusion versus exclusion - Penninx and Roosblad found a divergence comparable to that of the first dilemma: on the formal ideological level, none of the unions excluded migrant workers, but the practice of inclusion differed markedly across the seven countries. First, the degree of organization of migrant workers turned out to be much more determined by structural (national) characteristics of the trade unions than by characteristics of migrants themselves. It was very high in Sweden, where the general membership density of unions was the highest ( 82.5 per cent), and very low in France, where only 10.8 per cent of workers were organized. Secondly, being a member of the union does not always mean having the same rights. Although Swedish, German and Dutch trade unions negotiated equal industrial rights for migrant workers from the beginning, this did not necessarily imply equal social rights, such as access to state-controlled unemployment and social assistance benefits and rights of residence. In the Austrian case, the weak position of migrants 
compared with native workers was at least partly due to the pressures 'to protect native workers': migrants could be forced to leave the country if they could not find employment; migrants had to be laid off before native workers; they had unequal access to unemployment benefits; and they had no access to works councils. In Austria, migrants were also excluded from any position in the union if they were not naturalized Austrian citizens. Switzerland had comparable regulations that excluded migrant workers in certain respects. It was only in the 1980s and 1990s that unions in Austria and Switzerland gradually moved away from such exclusionary practices.

As to the third dilemma - equal versus special treatment - a general trend observed was that most national trade union organizations had to admit, over the course of time, that the specific situation and characteristics of migrant workers demanded some form of special attention and policies. On a practical level, this led to basic special measures in the sphere of communication (languages) and organizational facilities, such as special commissions and secretariats. The timing of these special policies differed: in most cases they started in the 1970s, but Swiss unions, for example, were much later in pursuing these policies, and Austrian unions never adopted such initiatives. Taking up the special interests of migrant workers in collective bargaining or in crisis situations such as strikes, however, turned out to be a very sensitive matter everywhere and not easily achieved. Only in a few cases in the UK and France are labour conflicts in which migrant workers made specific claims, such as the opportunity to pray during work hours, documented. In one French case, the communist trade union CGT solved this dilemma by reformulating such claims as work-related claims of 'hygiene' (Lloyd 2000: 123).

The specific versus general treatment dilemma manifested itself most clearly in the internal organization of trade unions. The awareness that it was difficult for migrant workers to be properly represented within the union organization has in many cases led to special commissions and secretariats, but as a general rule these have remained marginal within the unions. A more fundamental approach, which was taken quite early by the Swedish and German trade unions, was to establish special training and positive action programmes that aimed to lead to migrant workers eventually taking up staff positions in the unions.

In their final analysis of the differences found in the seven cases, the authors concluded that each of the explanatory factors listed above, taken separately, had limited explanatory value. However, these factors coming together within a specific historical and national context did explain the differences between countries. In all countries, trade union policies towards immigration and migrants proved to be influenced by national contextual factors such as the public discourse, institutional arrangements, legislation, 
and key institutional actors such as national authorities, churches or political parties. Although trade unions ideologically may have an internationalist orientation, their actual behaviour, action and effective influence has to be struggled for within national contexts (Penninx and Roosblad 2000). The way the dilemmas are resolved cannot be understood without knowledge of these national contexts.

\section{REVISITING THE ORIGINAL ANALYTICAL MODEL $^{2}$}

The Penninx and Roosblad book covered the guest worker system and (post-)colonial migration in north-west Europe from the 1960s until the 1990s. Since that period, major changes in a number of domains have created a new context for trade union action in general, and in relation to migrant workers in particular. The process of European enlargement and the framework of free movement, for instance, have introduced an 'unprecedented degree of inequality' across Europe (Meardi 2012: 104). In many European countries, racism and Islamophobia are increasingly present in society as well as in the political debate, and populist right-wing parties are receiving increasing support from the working class. A first step in the preparation of this book was therefore to reconsider the basic questions of the previous study within this context. Is the heuristic approach by Penninx and Roosblad still useful today in view of the changes in the contextual conditions? Or should that approach be redefined to reflect the increased complexities? We first look at the validity of the three basic dilemmas and reformulate these where necessary.

As to the first dilemma - whether trade unions should cooperate or resist the recruitment of migrant workers - we argue that the conditions under which trade unions face this dilemma have changed significantly. First, migration has become an important feature of more European countries, not just those in north-west Europe. Secondly, trade unions are now much less involved in corporate decision-making, particularly regarding immigration. Thirdly, more immigration takes place under the free movement regime within the enlarged European Union (EU), in which a completely new set of rules applies (see Chapter 3 ).

The dilemma nowadays is whether trade unions, as social and political actors, try to influence regulations on immigration and migrant workers' access to labour markets by opposing or supporting supranational provisions and government policies on immigration and mobility. While most European trade unions have formally abandoned their past restrictive stances towards immigration, they have nevertheless raised concerns about 
the effects of migration and especially intra-EU mobility on national labour markets and standards (Krings 2009; Cremers 2011; Meardi 2012; for a perspective from the sending countries, see Woolfson 2007). This suggests that the challenges posed by labour immigration and mobility are similar to those reported in the earlier Penninx and Roosblad study and leads us to conclude that the first dilemma is still valid, although it should be applied in a broader sense. The question is whether trade unions try to influence national or supranational policies related to the free movement of workers and immigration (for instance, in the case of European enlargement) and whether they have succeeded in influencing rules and regulations on such issues.

In relation to the second dilemma - inclusion versus exclusion - it has been noted how most European trade unions have 'renewed' their emphasis on notions such as international solidarity and equality and have embraced more inclusive attitudes compared to earlier periods (for instance, Avci and McDonald 2000; Haus 2002; Marino 2012; Adler et al. 2014). Union-inclusive stances have also been increasingly visible in the international arena in the form of coordination between trade unions of different European countries ${ }^{3}$ and in actions taken within the International Labour Organization (ILO), which have been fundamental for the ratification of a series of relevant Conventions - on migrant workers, domestic workers, trafficking and forced labour - and to support for the ILO's Decent Work Agenda.

However, despite formal inclusive policies at national and international levels, in practice the extent to which trade unions act to promote inclusion may vary under the pressures of current conditions. For example, the growth of intra-EU mobility gives new impetus to the 'old' debate as to whether today's migrants should be included as trade union members, considering the largely 'temporary' nature of such mobility which makes the unions' task of organizing these migrants more difficult (Fitzgerald and Hardy 2010). Migrants have also become more difficult to organize owing to a greater variation in their legal, labour market and social statuses (see Chapters 2 and 3) which makes their interests and needs different from native workers. Furthermore, anti-migrant and populist political discourse and the inadequacy of administrative facilities often leave migrants in a vulnerable position (see Chapter 4). Trade unions may therefore be called upon to address issues well beyond labour claims and labour equality, increasingly involving the social and legal status of migrant workers. This is especially true for the significant proportion of migrants who are irregular and undocumented and whose representation involves aspects that are not strictly labour associated, such as assistance in the regularization of residence and work and gaining access to housing and public services. This 
civic and political engagement might result in a rethinking of strategies and coalitions as well as the promotion of internal organizational and cultural changes (Hyman and Gumbrell-McCormick 2011; see also Chapter 5).

The foregoing observations lead us to conclude that the inclusionversus-exclusion dilemma is still valid but that a wider concept of 'inclusion' might be applied. Inclusion might be considered as 'full recognition of migrant workers as having the same social, employment, political and "organisational" rights as all other workers and members, being able to join the organisation at all levels and to participate in both internal debates and the formation of general strategies' (Marino 2013: 54). This definition implies that, in order to support and promote the inclusion of migrant workers, trade unions need to adopt policies and measures in the labour market and in the workplace, but also within unions and in the wider social sphere. The central question then becomes: to what extent do trade unions protect migrant workers' interests in these different domains? From an analytical viewpoint, these observations suggest considering the 'inclusion-versus-exclusion' dilemma in a closer inter-relationship with the third dilemma: 'equal-versus-special treatment'. They also suggest observing a wider range of union strategies and measures within and beyond the 'traditional' realm of union action. Therefore, 'representation' of migrant workers by unions includes strategies built along collective and individual dimensions, to defend both the labour and social rights of migrants. 'Organizing' includes initiatives aimed at involving migrant workers in trade union action by the means of union campaigns and disputes. It also refers to the recruitment of migrant workers as members as well as the provision of support for their self-organization and voice within the union.

If we have then accepted the three dilemmas in an adapted and redefined form, the next question is whether the four sets of explanatory factors are still meaningful under the conditions of the last two decades. The first factor identified by Penninx and Roosblad (2000: 13-14), was the power position of trade unions in society, which was strongly linked to the position of trade unions in national socio-economic decision-making processes. Trade union power (at the national level) went together with a high degree of organization, the maintenance of strong ties with the governing political parties, and a strongly centralized and unified structure.

Recent research presents interesting findings, particularly in relation to the workings of this factor for the inclusion dilemma. On the basis of trade union responses to migrants in Denmark and the United Kingdom, Wrench links the more inclusive stance on immigration and 'race' of the British trade unions to a decline in their influence: 'as membership and power declined, it was increasingly recognized that the future of trade unionism depended on a more inclusive strategy which took seriously the 
problems and interests of previously marginalized groups' (Wrench 2004: 21). Krings (2009) reports similar findings when comparing trade union responses to immigration in Austria, Germany, Ireland, and the United Kingdom:

[I]n Britain the collapse of traditional bargaining institutions and a loss in union influence under the Conservative governments propelled unions into rethinking traditional union strategies, not least in terms of organizing new groups of 'atypical' employees. This has contributed to a re-appraisal of union strategies towards more marginalized groups such as migrant workers. (Krings 2009: 61-2)

Comparing Italian and Dutch trade unions, Marino (2012) suggests an inverse relationship between unions' institutional embeddedness and their commitment to representing migrant workers. Roosblad (2013) supports this finding based on observations of Dutch trade unions over the past decade. She suggests that the current weakening of the institutional embeddedness of Dutch trade unions prompted them to start actively incorporating new groups of workers, such as undocumented workers, into their organization (Roosblad 2013: 47). These ideas are also in line with the findings of quantitative analyses on migrant unionization across European countries (Gorodzeisky and Richards 2013; Kranendonk and de Beer 2016).

The foregoing examples suggest that the position of trade unions in society remains a potentially strong explanatory factor for cross-national differences but that the effects on the three dilemmas might not always go in the same direction. The changed conditions suggest furthermore that we should define power position not just as direct tripartite co-decisionmaking, but in a more open way, namely as the extent to which trade unions possess institutional power resources, including their embeddedness in society and in policy-making relevant to their potential rank and file membership, and including the coalitions that trade unions may form to carry out their role as a political actor in society.

The second set of explanatory factors of Penninx and Roosblad is the state of the economy and labour market as a predictor of trade union action. Their study concluded that these factors are important triggers for trade union action, but the effect of that action (beneficial or harmful to migrants) is dependent on other contextual variables. Many studies suggest important processes of economic development that have changed significantly the national contexts over recent decades (see Chapter 2 in this volume). The intensification of economic and financial globalization has further challenged national economies and their regulatory frameworks, exactly where trade unions have historically developed their positions of 
influence. The Europeanization process has posed similar and additional challenges to national trade unions (Hyman 2005), especially as a consequence of the progressive enhancement of economic freedoms to the detriment of the 'social dimension', that is workers' security and protection. As mentioned above, the freedom of movement of capital, labour and services in an enlarged Europe each embody specific threats to national trade unions (Meardi 2012).

Another relevant aspect relates to national government responses to these supranational developments. Following the economic crisis, their responses have been implemented within national contexts, in many cases in an attempt to comply with the requirements of fiscal stability contained in European policies. Many governments have implemented labour market and welfare reforms in order to make their economy more competitive and to promote employability (see Chapter 2). These policies and reforms differ across countries but in general have reinforced flexibility in the labour market. In turn, such policies have provided employers with a wide range of contractual forms which may be used to save on labour costs, such as temporary and part-time work, often organized through agencies, subcontracting, and the hiring of self-employed workers. This has contributed to a further segmentation of the labour market. Trade unions that are traditionally most active in the regulation of standard employment now have to define and represent the interests of a more flexible and less homogeneous labour force, and they have to do so without straining relationships with their traditional rank and file membership (GumbrellMcCormick 2011).

All these observations suggest (perceived or real) increased labour market competition and point to dynamics similar to those described in Penninx and Roosblad (2000). The status of the labour market, therefore, still seems to be a fundamental factor of influence, although more attention should be given to the transnational dynamics in Europe, particularly internal EU mobility. The illustrations cited above lead us to retain economic and labour market forces and situations as a set of explanatory factors, though formulated in a more open way.

The third set of factors of the explanatory model of Penninx and Roosblad (2000) - under the generic title of social and cultural trends in society - relates to national contextual factors such as national identity and ideology, public discourse, legislation, and political structure and orientation. The recent literature confirms the influence of this variable. Wrench (2004: 7), for example, asserts that specific characteristics such as the contrast between the 'consensus and conflict frames of reference' and the quality of the national political discourse are important factors in explaining cross-national differences. He especially stresses factors such 
as 'a more overtly racist, anti-migrant, and Islamophobic discourse by political leaders and the media' (Wrench 2004: 7). Indeed, elements such as racism, xenophobia and, recently, Islamophobia have received too little attention (Wrench 2007). If they are widespread within trade unions and workplaces and if they are incorporated into union policies and practices, they imply either hostile attitudes towards, or disinterest in, migrant workers. If widespread throughout society and among workers, they might pose a dilemma for unions in their interaction with their rank and file membership. In some cases, strongly anti-racist central policies may be combined with racism in workplaces, among workers and among union delegates. Two trends should be taken into account when retaining this set of factors in the explanatory model for this study: the first is the surge of nationalism as an ideological basis for the general exclusion of (foreign) others; the second is the rise of Islamophobia as a specific form of exclusion (see Chapter 4).

The last set of explanatory factors in the Penninx and Roosblad study (2000) refers to the characteristics of migrants. Interestingly, in the conclusions of the book the authors already stated that there were good reasons to rethink the hypothesized importance of migrant workers' cultural background and their pre-migration experiences with trade unions in their country of origin as a predictor of their membership and active participation in trade unions in Europe. The cross-national comparison made it clear that the inclusion efforts and procedures of trade unions in the country of destination were a much better predictor of membership and active participation of migrant workers than the question of which country the migrant workers came from and whether they had experiences with trade unions before arrival.

By extension of this argument, we now pose that we should particularly look at the characteristics of migrants that are attributed to them by the policies of the destination countries after their arrival. Labels given to the migrant by state regulation - labour migrant, family migrant, refugee and so on - in fact determine the migrants' legal status and their position in the labour market, for example, whether they are active in the formal or informal part of the economy, in new and still unorganized sectors, or in vulnerable work arrangements.

We therefore conclude that all four sets of factors, in amended form, are worth considering when explaining union attitudes towards immigration and migrants today. We also believe that it may be fruitful to complement these variables with an additional variable related to the history and rooted traditions of trade unions that might help to understand the way in which trade unions frame challenges posed by immigration and migrant workers (Frege and Kelly 2003). We refer in particular to the concept 
of union identity, as proposed by Hyman (2001). According to Hyman (2001: 1):

The dominant identities embraced by particular unions, confederations and national movements - themselves reflecting the specific contexts in which national organizations historically emerged (Crouch 1993) - have shaped the interests with which they identify, the conceptions of democracy influencing members, activists and leaders, the agenda they pursue, and the type of power resources which they cultivate and apply.

Hyman develops his analysis by identifying three ideal types of European trade unionism, each associated with a distinctive ideological orientation towards market, society and class (Hyman 2001). 'In the first, trade unions are interest organizations with predominantly labour market functions; in the second, vehicles for raising workers' status in society more generally and advancing social justice; in the third, "schools of war" in a struggle between labour and capital' (Hyman 2001: 1-2). All three ideal types of unionism are intrinsically contradictory and therefore they do not constitute stable models: over the course of time, historical models of unionism have moved from being based on one of these principles to be based on stable compromises between two.

The importance of union identity is confirmed by many studies on trade union representation of migrant workers. For instance, in analysing trade union involvement in the Living Wage campaign in London, Wills (2004) stresses that trade union efforts were influenced by the fit between these strategies and wider 'organizing priorities'. Similarly, Martínez Lucio and Perrett (2009) stress that trade unions' attitudes towards migrant workers are influenced by the specific ways in which unions perceive issues and build solutions based on interests, internal politics and organizational capacities. Marino (2012) argues that the attitude of the Italian trade union towards migrant workers is strongly shaped by its identity as a 'general' union promoting defence of the social rights of 'disadvantaged groups' and engagement with problems not strictly related to employment. Following Hyman's (2001) approach, Connolly et al. (2014) identify three main logics that inform trade union action towards migrant workers: class, race/ethnicity and social rights. These are used implicitly or explicitly in building representative action. The authors analysed the specific challenges posed by migration for union identity and strategy in the Netherlands, Spain and the UK, and showed how trade union renewal in relation to migration implied engaging with new logics of actions that had not been part of the historical trade union approach. 


\section{METHODOLOGICAL CONSIDERATIONS}

Consideration of the original analytical framework of Penninx and Roosblad (2000), in the light of contextual changes, has resulted in the revised analytical framework presented above. This framework has been used as a guideline for data collection and analysis of 11 country cases and as the compass for the comparative analysis in Chapter 17. We invited scholars who were experts in the field of trade unions and migrant workers to write country case studies based on secondary analysis of existing data and literature. To enhance comparability of the country case accounts, the authors were asked to answer a common set of questions derived from the analytical framework which has been discussed with all the contributors during a meeting held in Manchester, UK, in March 2015. To facilitate drawing comparisons even further, the authors were asked to structure the country study chapters consistently with the analytical framework. However, the diversity of the national case studies included in the volume, together with the varying availability of existing research and secondary data for each country, made a rigid uniformity in content and structure of the country chapters undesirable. Allowing for flexibility in the topics that were addressed and in the way the analysis was structured, did justice to the specific characteristics and historical and national context of each country.

Similarly, while attention has been devoted to the definition of common concepts and indicators, the chapter authors were encouraged to highlight the case studies' specificities. The terminology used in a given country is an integral part of the dominant discourse and is often a reflection of the specific historical, political and national context of that country. Insistence on uniform terminology cross-nationally would therefore result in a loss of analytical insight. This is especially the case with terms as 'migration', 'migrants' and 'migrant workers'. As Penninx points out in Chapter 3, it is important to speak of 'migrations' in the plural. He underlines that different types of migration impact labour markets differently, and consequently, have different relevance for trade unions. Furthermore, the term 'migrant', and who is considered to be a migrant, are perceived differently in various countries, depending on states' policies, historical contexts or public discourses. As such, each chapter offers a different understanding of the terms 'migrants' and 'migrant workers', reflecting the particular national perception of the terms and the use that trade unions make of them.

In choosing country cases, we aimed at having different national case studies with respect to immigration histories and institutional characteristics. We chose six 'old' West European immigration countries: Austria, 
France, the Federal Republic of Germany, the Netherlands, Sweden and the United Kingdom. All six had also been included in the 2000 study, which brings implicitly a historical comparative aspect to the study. Furthermore, we included three 'new' immigration countries, Ireland, Italy and Spain, and two new EU member states in Central Europe, the Czech Republic and Poland.

This book is a sequel to the Penninx and Roosblad (2000) volume, which covered the period 1960-93. The main focus of this book is on the subsequent period from 1990 until 2015.

\section{THE STRUCTURE OF THE BOOK}

A crucial issue that we had to address in preparing the book was a description and analysis of the relevant contextual changes that have taken place in Europe in the past 15 years. Such analysis is included in the first part of this book, which consists - apart from this introductory chapter - of four chapters providing analysis of the changed contextual conditions for trade union action and strategies regarding migration and migrant workers. In Chapter 2, Jason Heyes and Thomas Hastings make a comparative analysis of how labour markets and labour market policies have developed in Europe, focusing particularly on the aftermath of the financial and economic crisis of 2008. The chapter underlines how the transition from the European Economic Community of 12 European states before 1995 to the European Union that expanded to 28 members by 2015 has made for a significantly new context. The authors discuss how the neo-liberal social and economic policies of the EU strongly impacted on national labour markets all over Europe. That impact was not uniform, as transpires from the observed differences across countries.

In Chapter 3, Rinus Penninx outlines how immigration in Europe developed from the specific form of guest worker and (ex-)colonial immigration in its Western part until the end of the 1980s, towards a pervasive phenomenon in the twenty-first century. Immigration is more diverse than before in terms of origin, form and duration. This chapter also describes different immigration and integration regimes in different parts of the EU: trade unions are now seldom involved as co-regulators in such regulatory regimes, but they deeply influence their relationship with migrant workers. A special section in this chapter is dedicated to the EU regime for free mobility of EU citizens and of service provision, and underlines how national trade unions are increasingly confronted with workers whose legal status has changed from international migrants to internal migrants.

Chapter 4 aims to outline changes in the social context and specifically 
in the societal receptiveness for immigration and migrants. Alberta Giorgi and Tommaso Vitale discuss the alarming findings of an analysis of attitudes towards migrants in different parts of the EU and underline how hostile attitudes are increasingly underpinned by arguments of cultural and religious differences considered as threats. They show that unwelcoming if not hostile attitudes are reflected in the political sphere, in the media and in the public discourse. They also discuss how such attitudes are ultimately anchored in the institutional sphere of migration and integration policies where they may translate into restrictions of rights, vulnerable legal statuses and obligations to assimilate within host societies. Trade unions are part of societies that have developed such attitudes and policies, and their relationship with migrants will therefore also be shaped by them.

Chapter 5 looks at trade unions themselves. The three authors, Rebecca Gumbrell-McCormick, Richard Hyman and Magdalena Bernaciak, outline the different nature and characteristics of European trade unions and the challenges they nowadays face. The chapter also provides an overview of trade union responses and points out the influence of union ideologies and structures on their strategies, including those related to migrant and ethnic minority workers. They conclude their discussion by calling for an 'imaginative counter-offensive' on the side of trade unions which 'have to believe, and demonstrate, that a better future is possible'.

The second part of the book includes 11 chapters, each describing and analysing trade union attitudes to and actions around immigration and migrant workers within one specific national context. We have ordered the 11 country cases in three clusters: three generations of immigration countries, each of them representing a different history of immigration and thus a different experience for trade unions. In the first cluster, six 'first generation immigration countries' are brought together (Chapters 6-11). These countries, all in western Europe, had already experienced sizeable immigration in the period 1960-90. All six were also part of the earlier study edited by Penninx and Roosblad (2000).

The 'second generation of European immigration countries' are those countries that turned from emigration countries to immigration countries in the late 1980s: in the 1990s until 2008 their economies and immigration levels were booming, leading to a proportion of migrants in the total population that was in some cases higher than in the first-generation immigration countries. We have three countries in this cluster (Chapters 12-14) - Ireland, Italy and Spain.

Finally, we have a small cluster (Chapters 15 and 16) of two countries from Central Europe. The Polish case represents here a country in which emigration and transit migration are still the dominant migration patterns. The chapter reports more on how Polish trade unions relate to Polish 
workers going abroad than to (the modest group of) migrant workers in Poland, reflecting the country's priorities and preoccupations. In the Czech case, on the contrary, migrant workers are the central topic, reflecting the Czech case as an upcoming immigration country.

In Chapter 17 we provide a comparative analysis of the 11 case chapters. Taking the three dilemmas as the starting point, we try to find patterns in the attitudes and actions of the trade unions across the different countries. Do trade unions in different countries identify the same issues as topics to fight for or against? Do they have similar answers to comparable issues? Identifying patterns is here shorthand for describing similarities and differences at the same time. In the second part of the chapter, we come back to the explanatory sets of factors described above and comment on their power to explain these (patterns of) similarities and differences.

\section{NOTES}

1. International Migration, Integration and Social Cohesion in Europe (IMISCOE) was founded in 2004 as an EU-funded Network of Excellence of 19 research institutes in Europe and continued as a self-financed network after 2009. It currently has 36 member institutes and 500 individual members. They are organized in seven Standing Committees and 18 Research Groups, one of them being IITUE.

2. This section builds on an article published during the preparation of this book (Marino et al. 2015).

3. Examples include the Protocol between the TUC (United Kingdom) and CGTP-IN (Portugal) (http://www.ilo.org/dyn/migpractice/docs/84/2014\%20Protocol.pdf, accessed 2 August 2017), or the ACTRAV model agreement (http:/www.ilo.org/dyn/migpractice/ docs/208/Model.pdf, accessed 2 August 2017).

\section{REFERENCES}

Adler L.H., T. Maite and L. Turner (2014), Mobilizing against Inequality. Unions, Immigrant Workers, and the Crisis of Capitalism, Ithaca, NY: ILR Press.

Avci, G. and C. McDonald (2000), 'Chipping away at the fortress: Unions, immigration and the transnational labour market', International Migration, 38 (2), 191-213.

Connolly, H., S. Marino and M. Martínez Lucio (2014), 'Trade union renewal and the challenges of representation: Strategies towards migrant and ethnic minority workers in the Netherlands, Spain and the United Kingdom', European Journal of Industrial Relations, 20 (1), 5-20.

Cremers, J. (2011), In Search of Cheap Labour: Working and Living Conditions of Posted Workers, CLR Studies 6, Brussels: CLR/EFBWW/International Books.

Crouch, C. (1993), Industrial Relations and European State Traditions, Oxford: Clarendon Press.

Fitzgerald, I. and J. Hardy (2010), 'Thinking outside the box? Trade union 
organising strategies and Polish migrant workers in the United Kingdom', British Journal of Industrial Relations, 48 (1), 131-50.

Frege, C. and J. Kelly (2003), 'Union revitalization strategies in comparative perspective', European Journal of Industrial Relations, 9 (1), 7-24.

Gorodzeisky, A. and A. Richards (2013), 'Trade unions and migrant workers in Western Europe', European Journal of Industrial Relations, 19 (3), 239-54.

Gumbrell-McCormick, R. (2011), 'European trade unions and atypical workers', Industrial Relations Journal, 42 (3), 293-310.

Haus, L.A. (2002), Unions, Immigration, and Internationalization: New Challenges and Changing Coalitions in the United States and France, New York: Palgrave Macmillan

Hyman, R. (2001), Understanding European Trade Unionism: Between Market, Class and Society, London: Sage.

Hyman, R. (2005) 'Trade unions and the politics of European integration', Economic and Industrial Democracy, 26 (1), 9-40.

Hyman, R. and R. Gumbrell-McCormick (2011), 'Trade unions, politics and parties: Is a new configuration possible?', Transfer, 16 (3), 315-31.

Kranendonk, M. and P. de Beer (2016), 'What explains the union membership gap between migrants and natives?', British Journal of Industrial Relations, 54 (4), 846-69.

Krings, T. (2009), 'A race to the bottom? Trade unions, EU enlargement and the free movement of labour', European Journal of Industrial Relations, 15 (1), 49-69.

Lloyd, C. (2000), 'Trade unions and migrants in France: From assimilation to antiracist networking', in R. Penninx and J. Roosblad (eds), Trade Unions, Immigration and Migrants in Europe 1960-1993, New York: Berghahn Books, pp. 111-32.

Marino, S. (2012), 'Trade union inclusion of migrant and ethnic minority workers: Comparing Italy and the Netherlands', European Journal of Industrial Relations, 18 (1), 5-20.

Marino, S. (2013), 'Between old and new dilemmas: Describing trade unions' inclusive strategies', in A. van Heelsum and B. Garcés-Mascareňas (eds), Filling in Penninx's Heuristic Model, Amsterdam: Amsterdam University Press, pp. 50-61.

Marino, S., R. Penninx and J. Roosblad (2015), 'Trade unions, immigration and migrants in Europe revisited: Unions' attitudes and actions under new conditions', 3 (1), 1-16.

Martínez Lucio, M. and R. Perrett (2009), 'The diversity and politics of trade unions' responses to minority ethnic and migrant workers: The context of the UK', Economic and Industrial Democracy, 30 (3), 1-24.

Meardi, G. (2012), 'Union immobility? Trade unions and the freedoms of movement in the enlarged EU', British Journal of Industrial Relations, 50 (1), 99-120.

Penninx, R. and J. Roosblad (eds) (2000), Trade Unions, Immigration, and Migrants in Europe, 1960-1993: A Comparative Study of the Attitudes and Actions of Trade Unions in Seven West European Countries, New York and Oxford: Berghahn Books.

Penninx, R., M. Berger and K. Kraal (eds) (2006), The Dynamics of International Migration and Settlement in Europe: A State of the Art, Amsterdam: Amsterdam University Press.

Roosblad, J. (2013), 'Trade unions and the representation of migrant and ethnic minority workers: Challenges in deteriorating industrial relations', in A. van 
Heelsum and B. Garcés-Mascareňas (eds), Filling in Penninx's Heuristic Model, Amsterdam: Amsterdam University Press, pp. 35-49.

Wills, J. (2004), 'Organising the low paid: East London's living wage campaign as a vehicle for change', in G. Healy, E. Heery, P. Taylor and W. Brown (eds), The Future of Worker Representation, Oxford: Oxford University Press, pp. 264-82.

Woolfson, C. (2007), 'Labour standards and migration in the new Europe: Postcommunist legacies and perspectives', European Journal of Industrial Relations, 13 (2), 199-218.

Wrench, J. (2004), 'Trade union responses to migrants and ethnic inequality in Denmark and the UK: The context of consensus and conflict', European Journal of Industrial Relations, 10 (1), 7-30.

Wrench, J. (2007), 'Gathering evidence for racism and discrimination in the EU: The implications for trade unions', Transfer: European Review of Labour and Research, 13 (3), 488-96. 
Stefania Marino, Rinus Penninx, and Judith Roosblad - 9781788114080 Downloaded from PubFactory at 04/26/2023 10:17:38AM 